\title{
Zminiaturyzowane urządzenie pomiarowe do badań nieniszczących metodą prądów wirowych - Wirotest serii M
}

\author{
Miniaturized measuring device \\ for eddy current non-destructive testing - Wirotest M-series
}

\section{Streszczenie}

Artykuł opisuje metodę prądów wirowych oraz nowopowstałe zminiaturyzowane urządzenie pomiarowe do badań nieniszczących tą metodą - Wirotest M1. W pracy przedstawiono budowę i możliwości zastosowania urządzenia. Wirotest M1 cechuje się małą masą i gabarytami. Możliwość pracy z tabletem lub smartphonem nadaje mu cechy urządzania mobilnego. Urządzenie może pracować w trybie pomiaru ręcznego lub na stanowiskach automatycznych.

Słowa kluczowe: badania nieniszczące; metoda prądów wirowych; zminiaturyzowany układ pomiarowy; Wirotest M1

\begin{abstract}
This paper describes the eddy current method and the newly created miniaturized measuring device for non-destructive testing using this method - Wirotest M1. The work presents construction and possibilities of applications of the device. Wirotest M1 is characterized by a small mass and size. The ability to work with a tablet or a smartphone makes the device mobile. It can work in manual mode or it can be used on automatic stands.
\end{abstract}

Keywords: non-destructive testing; eddy current method; miniaturized measuring device; Wirotest M1

\section{Metoda prądów wirowych}

Badania nieniszczące znalazły szerokie zastosowanie w praktyce do oceny jakości i poprawności wykonania części maszyn i urządzeń. Są wykorzystywane zarówno na etapie procesu produkcyjnego, jak i do kontroli eksploatacyjnej. Jedną z metod badań nieniszczących jest metoda prądów wirowych (ET - Electromagnetic Testing lub Eddy Current Testing). Obok badań wizualnych (VT), metody penetracyjnej (PT) oraz metody magnetycznej (MT), metoda ET należy do grupy powierzchniowych metod badań nieniszczących [1,2].

Główne kierunki wykorzystania metody prądów wirowych to wykrywanie wad materiałowych - defektoskopia, badania właściwości materiałów - strukturoskopia oraz określanie wymiarów (głównie pomiary grubości). Metoda ta pozwala na badanie różnorodnych materiałów, pod warunkiem, że są one przewodnikami prądu elektrycznego.

Podstawowym zjawiskiem wykorzystywanym w badaniach metodą prądów wirowych jest indukcja elektromagnetyczna, która polega na indukowaniu prądu w materiale przewodzącym, w wyniku działania na niego zmiennego pola magnetycznego. W zastosowaniach metody ET zmienne pole magnetyczne występuje wskutek zasilania cewek indukcyjnych prądem zmiennym.
Podstawy metody prądów wirowych można opisać w następujących punktach (rys. 1):

1. Przez cewkę przepływa prąd zmienny I;

2. W cewce, jak i wokół niej, indukowane jest zmienne pole magnetyczne $\mathrm{H}$;

3. Zmienne pole magnetyczne $\mathrm{H}$ wnika $\mathrm{w}$ badany materiał indukując w nim prądy wirowe EC;

4. Prądy wirowe EC indukują swoje własne pole magnetyczne $\mathrm{H}_{\mathrm{EC}}$;

5. Pole magnetyczne $\mathrm{H}_{\mathrm{EC}}$ oddziałuje (osłabia) pole $\mathrm{H}$.

$$
\begin{gathered}
\text { Materiał badany jednorodny } \rightarrow \text { stałe osłabienie } \\
\text { Zmiany } w \text { materiale badanym } \rightarrow \text { zmiana osłabienia }
\end{gathered}
$$

Ścieżki przebiegu indukujących się prądów wirowych zależą od fizycznych własności badanego materiału. Od nich zależy też dobór parametrów kontroli wiroprądowej. Do najistotniejszych, z punktu widzenia metody ET, należą właściwości elektromagnetyczne [2]:

- przewodność elektryczna właściwa $\gamma$,

- przenikalność magnetyczna względna $\mu_{\mathrm{r}}$.

Mgr inż. Adam Kondej, inż. Artur Szczepański - Instytut Mechaniki Precyzyjnej.

Autor korespondencyjny/Corresponding author. adam.kondej@imp.edu.pl 


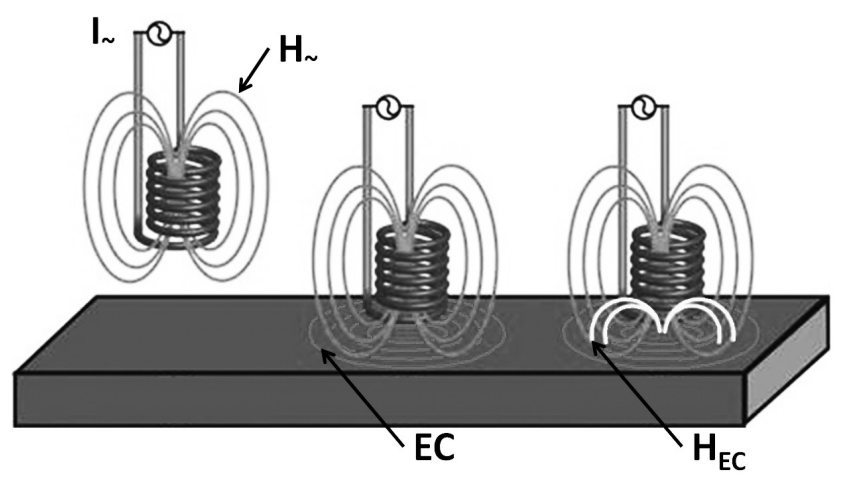

Rys. 1. Podstawy metody prądów wirowych

Fig. 1. Basics of the eddy current method

Prądy wirowe płyną przez miejsca o większej przewodności elektrycznej, natomiast miejsca o mniejszej przewodności są przez nie opływane (rys. 2). Wszelkie zmiany w badanym materiale, jak zmiana twardości, zmiana struktury, nieciągłości itd., wpływają na wartość parametrów elektromagnetycznych (tabl. I), a tym samym na wartość natężenia prądów wirowych i indukowanego pola magnetycznego. Analiza wartości amplitudy sygnału wyjściowego, bądź amplitudy i przesunięcia fazowego pozwala na ocenę stanu badanego materiału $[1 \div 4]$.

a)

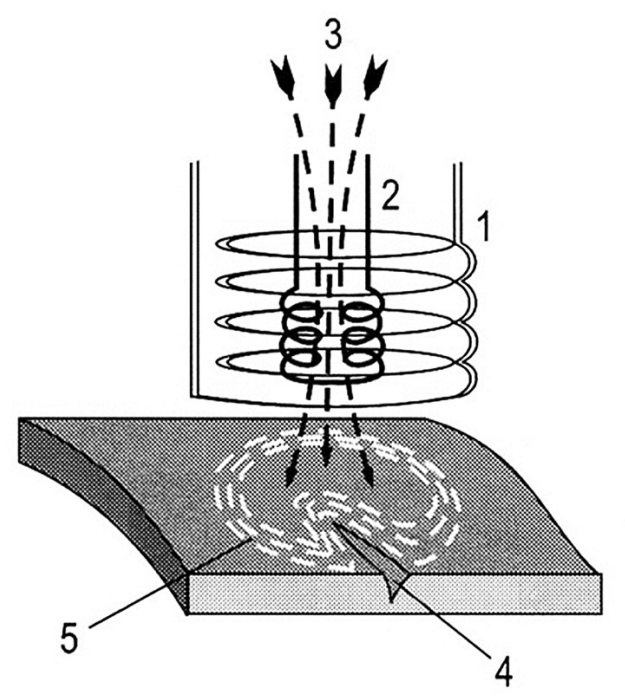

b)

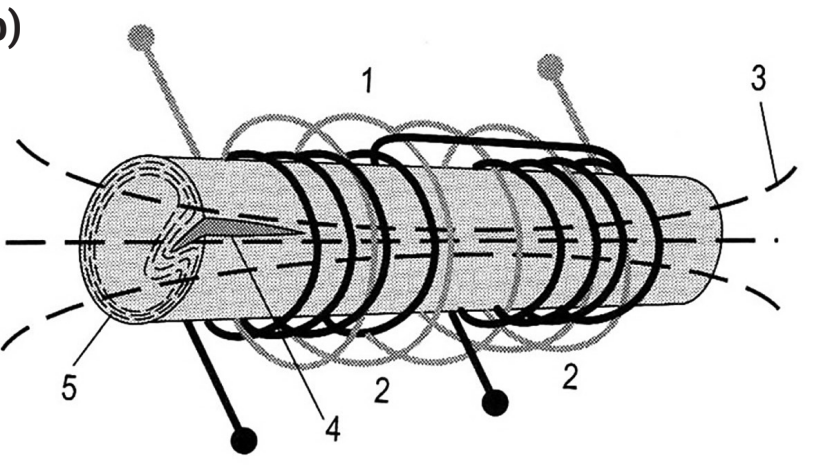

Rys. 2. Linie sił pola magnetycznego i linie przepływu prądów wirowych: a) sonda stykowa, b) sonda przelotowa; 1 - uzwojenie wejściowe, 2 - uzwojenie wyjściowe, 3 - linie sił pola magnetycznego, 4 - nieciągłość materiałowa (pęknięcie), 5 - linie przepływu prądów wirowych [3]

Fig. 2. The lines of force of the magnetic field and the eddy current flow: a) surface probe, b) encircling coil; 1 - input coil, 2 - output coil, 3 - the lines of force of the magnetic field, 4 - material discontinuity (crack), 5 - the eddy current flow lines [3]
Tablica I. Wpływ wybranych czynników na przewodność elektryczną właściwą i przenikalność magnetyczną względną

Table I. The influence of selected factors on electrical conductivity and relative permeability

\begin{tabular}{|c|c|c|c|}
\hline Lp. & Rodzaj czynnika & $\begin{array}{c}\text { Przewodność } \\
\text { elektryczna } \\
\text { właściwa, } \\
\text { Y }\end{array}$ & $\begin{array}{c}\text { Przenikalność } \\
\text { magnetyczna } \\
\text { względna, } \\
\mu_{\mathrm{r}}\end{array}$ \\
\hline 1 & Skład chemiczny & ++ & + \\
\hline 2 & Struktura & - & ++ \\
\hline 3 & Wydzielenia & + & ++ \\
\hline 4 & Naprężenia wewnętrzne & + & ++ \\
\hline 5 & Pęknięcia & ++ & + \\
\hline
\end{tabular}

Do określenia głębokości wnikania prądów wirowych służy standardowa głębokość wnikania prądów wirowych. Nie określa ona rzeczywistych wartości głębokości, natomiast stanowi głębokość wnikania prądów wirowych, przy których amplituda tych prądów zmniejsza się e-krotnie, czyli ok. 2,72 razy, w stosunku do amplitudy na powierzchni materiału.

Standardowa głębokość wnikania jest opisana zależnością (1):

$$
\delta=503 / \sqrt{\left(f \cdot \gamma^{\bullet} \mu_{r}\right)}
$$

gdzie:

ठ - standardowa głębokość wnikania prądów wirowych [mm], $\mathrm{f}$ - częstotliwość pracy przetwornika [Hz],

y - przewodność elektryczna właściwa materiału [MS/m], $\mu_{\mathrm{r}}$ - przenikalność magnetyczna względna elementu, bezwymiarowa.

Im wyższe są wartości częstotliwości pracy przetwornika wiroprądowego, przewodności elektrycznej właściwej materiału i przenikalności magnetycznej względnej badanego elementu, tym standardowa głębokość wnikania prądów wirowych jest mniejsza.

Wpływ niezgodności materiałowych oraz zmian strukturalnych na sygnały przetworników jest ograniczony do tzw. efektywnej głębokości wnikania prądów wirowych. Jest to głębokość około trzech standardowych głębokości wnikania prądów wirowych (3ठ) [5].

Wybór częstotliwości pracy urządzenia pomiarowego zapewnia możliwość regulowania głębokości wnikania prądów wirowych, a tym samym wybór obszarów, jakie mają być kontrolowane. Do badania warstw wierzchnich stosuje się przetworniki o wysokiej częstotliwości pracy (rzędu kil$\mathrm{ku} \mathrm{MHz}$ ). Natomiast do wykrywania niezgodności i zmian strukturalnych na pewnej głębokości od powierzchni należy używać przetworników o niższej częstotliwości (rzędu od kilku do kilkuset kHz) [5].

Podczas pomiarów metodą prądów wirowych określa się zmianę wskazań urządzenia pomiarowego w odniesieniu do poziomu przyjmowanego za prawidłowy. Poziom ten ustala się na powierzchni elementu bez wad i o takiej samej strukturze jak materiał badany. Metoda ma więc charakter porównawczy i wymaga korzystania ze wzorców bądź próbek odniesienia. 


\section{Koncepcja zminiaturyzowanego urządzenia pomiarowego metodą ET}

Koncepcja opracowania zminiaturyzowanego urządzenia do badań nieniszczących metodą prądów wirowych powstała w wyniku zapotrzebowania na proste urządzenie pomiarowe, mogące pracować $w$ trybie ręcznym i/lub automatycznym, charakteryzujące się stabilną pracą zarówno w warunkach laboratoryjnych, jak i przemysłowych. Zapytania ofertowe od przedsiębiorstw produkcyjnych o możliwość aplikacji urządzeń produkcji IMP do badań ET na linii produkcyjnej były głównym bodźcem do podjęcia prac nad stworzeniem nowego urządzenia, pozwalającego na zaspokojenie potrzeb rynku.

Inspiracją do stworzenia zminiaturyzowanego urządzenia pomiarowego była praca statutowa zrealizowana w IMP przez inż. Tadeusza Kuśmierczyka w 2009 roku (nr 13.1.01.292.00), w wyniku której powstała aktywna sonda indukcyjna, będąca przedmiotem zgłoszenia patentowego (nr PL409286). W odróżnieniu od sondy aktywnej, będącej także urządzeniem pomiarowym niewielkich rozmiarów, koncepcja nowego urządzenia zakładała bardziej uniwersalny jego charakter - przede wszystkim możliwość zmiany częstotliwości pracy.

W ramach pracy statutowej w 2017 roku opracowano i wykonano prototyp urządzenia do badań ET - Wirotest M. Nazwa "Wirotest” nawiązuje do tradycji nazewnictwa urządzeń produkcji IMP do badań nieniszczących metodą prądów wirowych, natomiast oznaczenie serii "M" pochodzi od słowa "Miniature". Prototyp posiadał zintegrowaną sondę stykową, pracującą z zadaną częstotliwością, bez możliwości jej zmiany. Po sprawdzeniu skuteczności działania urządzenia prototypowego wykonano docelowe urządzenie - Wirotest M1.

\section{Budowa i działanie Wirotestu M1}

Wirotest M1 pracuje z urządzeniem zewnętrznym typu komputer, tablet lub smartphone (wymagane wsparcie USB OTG), będącym źródłem zasilania oraz jednostką zbierającą, wyświetlającą i archiwizującą dane pomiarowe. Zasilanie i komunikacja odbywa się poprzez port USB typu B. Urządzenie rejestruje zmiany napięcia cewki - pomiar amplitudowy, z szybkością 8 pomiarów na sekundę. Istnieje możliwość ustawienia częstotliwości próbkowania w zakresie od 5 do 4500 pomiarów na sekundę na etapie montażu urządzenia. Należy jednak pamiętać, że zwiększenie częstotliwości próbkowania powoduje obniżenie czułości pomiaru. Schemat blokowy Wirotestu M1 przedstawiono na rysunku 3, natomiast ilustrację urządzenia zamieszczono na rysysunku 4.

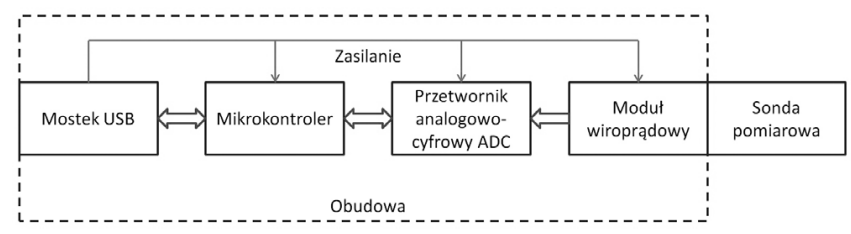

Rys. 3. Schemat blokowy Wirotestu M1

Fig. 3. The Wirotest $\mathrm{M} 1$ block scheme

Głównym elementem zarządzającym pracą całego urządzenia jest mikrokontroler STM32F103x pracujący na rdzeniu Cortex-M3. Moc obliczeniowa oraz możliwości jakie posiada ww. układ pozwalają na dodawanie w przyszłości nowych opcji pracy w zależności od wymaganych potrzeb.

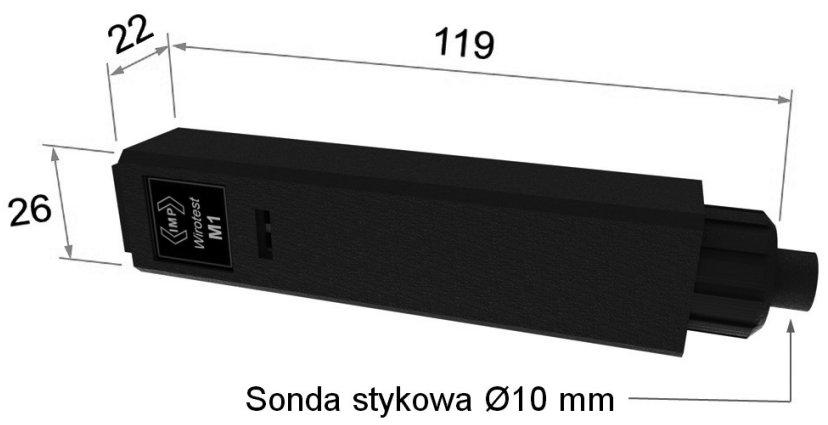

Rys. 4. Wirotest $M 1 \mathrm{z}$ sondą stykową (waga $35 \mathrm{~g}$ bez sondy pomiarowej) Fig. 4. Wirotest M1 with surface probe (weight $35 \mathrm{~g}$ without measurement probe)

Głównym zadaniem mikrokontrolera w tym urządzeniu jest konfiguracja przetwornika analogowo-cyfrowego oraz przetwarzanie i wysyłanie danych poprzez mostek USB. W tym konkretnym zastosowaniu nie został wykorzystany wbudowany mostek USB w mikrokontrolerze. Wynika to z przyjętych założeń, pozwalających na łatwe zastąpienie wyjścia USB typu B dowolnym innym łączem szeregowym (np. EIA-232, EIA-485) bez konieczności gruntownej modyfikacji kodu źródłowego.

Elementem przetwarzającym analogowy sygnał z modułu wiroprądowego jest przetwornik AD7190 wraz z napięciem referencyjnym ADR3425. Uzyskanie niskiego poziomu szumów przetwornika było możliwe dzięki zastosowaniu trzech technik: 1. Płytka PCB została wykonana w technologii czterowarstwowej z wydzielonymi dwiema warstwami dla dystrybucji zasilania do poszczególnych układów.

2. Zastosowano miejscowo filtry RLC w celu izolowania szczególnie wrażliwych układów oraz zmniejszenia propagacji zakłóceń po liniach zasilania.

3. Zastosowano źródło napięcia referencyjnego pracującego w konfiguracji cztero-przewodowej.

W urządzeniu nie zastosowano podziału na masę analogową i cyfrową z uwagi na brak wyraźnego miejsca podziału między częścią cyfrową i analogową. W urządzeniach, w których występuje analogowy tor pomiarowy oraz cyfrowa część przetwarzająca sygnał, częstym sposobem zmniejszenia wpływu zakłóceń na tor pomiarowy jest separacja obwodów zasilania wraz z separacją obwodu masy układu dla części cyfrowej i analogowej. Tego typu rozwiązanie sprawdza się, kiedy możemy w łatwy sposób rozdzielić elementy cyfrowe od elementów analogowych. W przypadku kiedy takiego podziału nie można przeprowadzić, wprowadzenie sztucznego rozdzielenia masy na część cyfrową i analogową może doprowadzić do zwiększenia zakłóceń w stosunku do rozwiązania nieposiadającego takiego podziału [6].

Wymienna sonda pomiarowa jest elementem modułu wiroprądowego. Cewka sondy jest wzbudzana z generatora i stanowi element obwodu rezonansowego. Zmieniając cewkę oraz zestaw kondensatorów możliwa jest zmiana częstotliwość pracy urządzenia. Rozwiązanie konstrukcyjne obudowy pozwala na łatwą i szybką wymianę tych elementów, bez konieczności użycia jakichkolwiek narzędzi.

\section{Możliwości i zastosowanie Wirotestu M1}

Wirotest M1 jest przeznaczony do pracy z przetwornikami bezwzględnymi, stykowymi oraz przelotowymi. Dedykowane sondy montowane są bezpośrednio w obudowie urządzenia (rys. 4). Zastosowanie adaptera ze złączem koncentrycznym LEMO pozwala na podłączenie kablem sond 


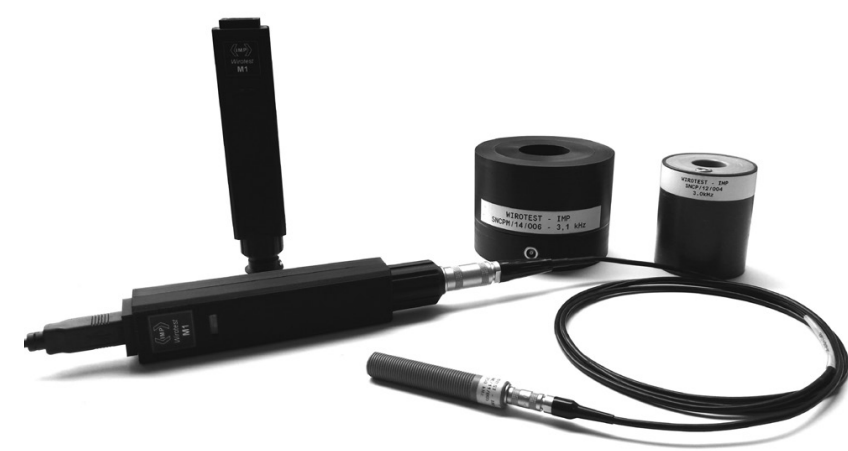

Rys. 5. Przykłady sond pomiarowych pracujących z Wirotestem M1 Fig. 5. Examples of measuring probes working with Wirotest M1

stykowych typu SNC oraz przelotowych, współpracujących z defektoskopami Wirotest 302 oraz Wirotest 1000 produkcji IMP (rys. 5).

Urządzenie nie ma możliwości kalibrowania. Po podłączeniu danej sondy z zestawem kondensatorów pracuje z zadaną częstotliwością oraz czułością. Korzystając ze wzorców, należy sprawdzać okresowo poprawność działania urządzenia. Zrezygnowanie z przycisków i pokręteł wyeliminowało ryzyko zmiany ustawień przez użytkownika w sposób przypadkowy. Wirotest M1 cechuje się łatwą i intuicyjną obsługą, nie wymaga długiego szkolenia stanowiskowego.

Wirotest M1 może być wykorzystywany do pracy w trybie ręcznym, np. jako przenośny defektoskop. Możliwość podłączenia z tabletem lub smartphonem nadaje Wirotestowi M1 charakter urządzenia mobilnego, poręcznego, o małej masie i gabarytach. Porównanie Wirotestu M1 z klasycznym defektoskopem przenośnym produkcji IMP przedstawiono na rysunku 6.

Duża częstotliwość próbkowania oraz komunikacja poprzez port USB sprawia, że Wirotest M1 nadaję się do pracy w trybie automatycznym. Ograniczeniem ilości urządzeń pracujących na stanowisku jest liczba portów, jakie obsługuje jednostka sterująca. Przykład zastosowania Wirotestu M1 na stanowisku automatycznym AutoWir-S1 do kontroli kół zębatych przedstawiono na rysunku 7 .

Ze względu na stabilną pracę oraz odporność na działanie czynników zewnętrznych urządzenie może pracować w warunkach laboratoryjnych oraz przemysłowych (rys. 8), $\mathrm{np}$. do kontroli międzyoperacyjnej półfabrykatów, końcowej kontroli jakości gotowych wyrobów, a także do kontroli eksploatacyjnej pracujących już części.

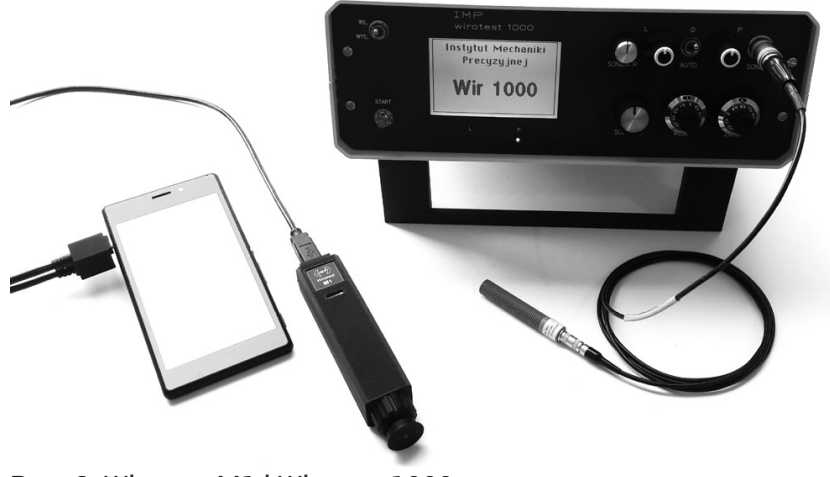

Rys. 6. Wirotest M1 i Wirotest 1000

Fig. 6. Wirotest M1 and Wirotest 1000

Wirotest M1 może znaleźć zastosowanie do:

- wykrywania niezgodności i wad materiałowych,

- wykrywania zmian strukturalnych,

- rozróżniania i sortowania materiałów,

- oszacowania twardości powierzchniowej,

- pomiarów grubości warstw i powłok.

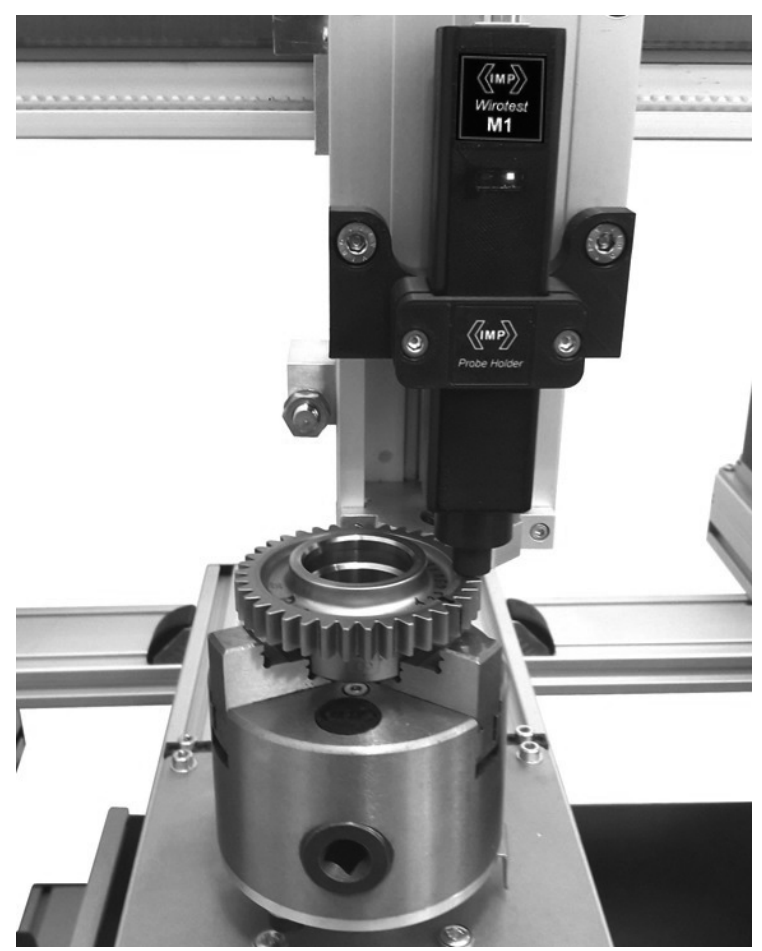

Rys. 7. Pomiar automatyczny z wykorzystaniem Wirotestu M1 na stanowisku AutoWir-S1

Fig. 7. Automatic measurement using Wirotest M1 on AutoWir-S1

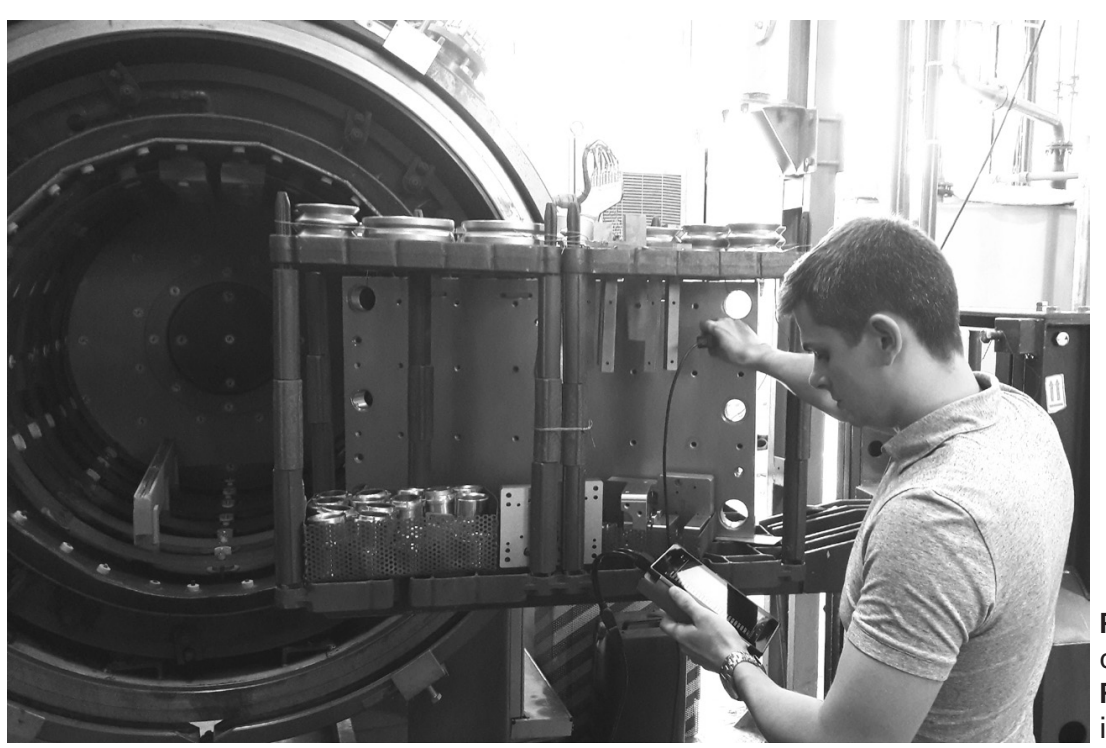

Rys. 8. Inspekcja części po obróbce cieplnej w piecu próżniowym (Centrum Obróbki Cieplnej IMP) Fig. 8. Inspection of parts after a heat treatment in vacuum furnace (Heat Treatment Center IMP) 


\section{Podsumowanie}

Opracowanie i wykonanie zminiaturyzowanego urządzenia pomiarowego do badań nieniszczących metodą prądów wirowych rozszerza możliwości pracy badawczej i wdrożeniowej Instytutu w tym obszarze. Stworzenie Wirotestu M1 pozwala na opracowywanie rozwiązań problemów spotykanych w przedsiębiorstwach produkcyjnych w oparciu o urządzenia pomiarowe własnej konstrukcji.

Wirotest M1 charakteryzuje się małą masą i gabarytami, może pracować z tabletem lub smartphonem, jest urządzeniem mobilnym, łatwym w obsłudze. Może znaleźć zastosowanie jako przenośny defektoskop, bądź jako urządzenie pomiarowe pracujące na linii automatycznej.

Badania oraz wykonanie układu pomiarowego zrealizowano w Instytucie Mechaniki Precyzyjnej w ramach pracy statutowej w 2017 r. pt. „Opracowanie zminiaturyzowanego układu pomiarowego do badań nieniszczących metodą prądów wirowych", nr 13.1.01.416.00.

\section{Literatura}

[1] Dybiec Cz., Włodarczyk S.: Badania nieniszczące metodą prądów wirowych - możliwości zastosowań, Ochrona przed korozją, nr 3, s. 67-74, 2010.

[2] Lewińska-Romicka A.: Defektoskopia wiroprądowa, Poradnik, Biuro Gamma, Warszawa 1997.

[3] Lewińska-Romicka A.: Badania nieniszczące, Podstawy defektoskopii, Wydawnictwa Naukowo-Techniczne, Warszawa 2001.
[4] Lewińska-Romicka A.: Badania materiałów metodą prądów wirowych, Biuro Gamma, Warszawa 2007.

[5] Kondej A., Baranowski M., Niedźwiedzki K., Jończyk. S., Szczepański A.: Automatyczne stanowisko do badań nieniszczących metodą prądów wirowych, Inżynieria Powierzchni, nr 1, s. 57-62, 2014.

[6] Kester W.: Practical design techniques for sensor signal conditioning, Analog Devices, USA 1999. 